УДК 349.22

DOI https://doi.org/10.32844/2618-1258.2019.3-2.3

ПАНЧЕНКО М.В.

\title{
МЕТА Й ЦІЛІ ФУНКЦІОНУВАННЯ ПРАВОВОГО МЕХАНІЗМУ ЗАБЕЗПЕЧЕННЯ ГІДНОЇ ПРАЦІ ДЕРЖАВНИХ СЛУЖБОВЦІВ
}

\begin{abstract}
Метою наукової статті є окреслення загальної мети й похідних від неї стратегічних цілей функціонування правового механізму забезпечення гідної праці державних службовців в Україні. Функціонування правового механізму забезпечення гідної праці державних службовців в Україні, як і будь-який конструктивний соціально-правовий феномен, проявляє себе в практичній дійсності відповідно до певної мети. При цьому в науці трудового права до сьогодні не встановлено мети і стратегічних цілей функціонування відповідного правового механізму. Вирішуючи цю теоретико-практичну проблему, автор, установлюючи сутнісний зміст загальнонаукового поняття «мета», а також беручи до уваги сформульоване ним визначення поняття «функціонування правового механізму забезпечення гідної праці державних службовців», окреслює загальну мету й перелік основних стратегічних цілей функціонування відповідного правового механізму. Визначено стратегічні напрями функціонування правового механізму забезпечення гідної праці зазначених суб'єктів трудового права: у нормативному напрямі; у адміністративно-правовому напрямі; у інформаційно-заохочувальному напрямі; у концептуально-адаптивному напрямі; у напрямі превентивної, правозахисної та правовідновлювальної діяльності. Зроблено висновок, що правовий механізм забезпечення гідної праці державних службовців $\epsilon$ юридичною конструкцією, у межах функціонування якої здійснюється діяльність, об'єктивуються процеси, які окремо чи сукупно підтримують рівень відповідності праці на державній службі критеріям гідної праці, сприяють подальшому впровадження ідеї гідної праці, а також захисту права держслужбовця на гідну працю, усувають суб' єктів, що становлять загрозу для панування концепції гідної праці в державних органах. Раціональне функціонування розглядуваного механізму є можливим тоді, коли його функціонування підпорядковано не лише завданням, a i ïx систематичному досягненню головним чином у межах відповідних напрямів об'єктивації правового механізму, а саме в нормативному напрямі; суто адміністративно-правовому напрямі; інформаційно-заохочувальному напрямі; концептуально-адаптивному напрямі; напрямі превентивної, правозахисної та правовідновлювальної діяльності.
\end{abstract}

Ключові слова: гідна прачя, державна служба, державний службовець, правовий механізм, функиіонування правового механізму.

The purpose of the scientific article is to outline the general purpose and the strategic goals derived from it of functioning of the legal mechanism for ensuring decent work of civil servants in Ukraine. The functioning of the legal mechanism for ensuring decent work for public servants in Ukraine, like any constructive social and legal phenomenon, manifests itself in accordance with a specific goal in practical reality. At the same time, the purpose and strategic goals of the corresponding legal mechanism functioning have not yet been established in the science of labor law. Solving this theoretical and practical problem, the author, while establishing the essential content of the general scientific concept of "goal", as well as considering the definition of the "functioning of the legal mechanism for ensuring decent work of public servants" concept, defines the general purpose and the list of main strategic goals for the functioning of the related legal mechanism. The strategic directions of functioning of the legal mechanism of ensuring decent work of the mentioned subjects of labor law are determined: in the normative direction; in the administrative-legal direction; in the information-promoting direction; in conceptual and adaptive direction;

(c) ПАНЧЕНКО М.В. - кандидат юридичних наук, адвокат 
towards preventive, human rights and restorative activities. It is concluded that the legal mechanism for ensuring decent work of civil servants is a legal structure within the functioning of which the activity is carried out; the protection of the right of a civil servant to decent work is eliminated by entities that pose a threat to the domination of the concept of decent work in government bodies. The rational functioning of the mechanism under consideration is possible when its functioning is subordinated not only to the task, but also to their systematic achievement, mainly within the relevant directions of objectification of the legal mechanism, namely in: the normative direction; purely administrative and legal direction; information and promotion direction; conceptual-adaptive direction; direction of preventive, human rights and restorative activities.

Key words: civil servant, civil service, decent work, functioning of the legal mechanism, legal mechanism.

Вступ. Держава являє собою певну систему, механізм, який «в залежності від наявних у ньому складових частин та їх взаємодії функціонує задля досягнення поставленої мети». Крім того, як зазначає український учений М.I. Зубрицький, діяльність будь-якого сучасного державного утворення спрямована на забезпечення задоволення інтересів усіх верств населення задля досягнення злагоди в суспільних правовідносинах. «Без здійснення цих умов на державу чекатиме революція та занепад, які матимуть своїм наслідком тотальне реформування даної суспільно-політичної організації» [1, с. 105]. У свою чергу, вітчизняна вчена Н.I. Бернацька зауважує, що досягнення результативності можливе за умови чіткого планування, що включає в тому числі й визначення мети, завдань і функцій правового регулювання соціального забезпечення публічної служби в Україні. «Важливість встановлення мети правового регулювання соціального забезпечення публічної служби в Україні полягає у тому, що шляхом визначення даної категорії відбувається завчасна побудова комплексу дій, які варто здійснити у даному процесі. Саме для цього у науці передбачено існування категорії «завдання», що встановлюється для забезпечення досягнення мети» [2, с. 121, 122].

3 викладеного випливає актуальність 3'ясування мети й комплексу цілей функціонування правового механізму забезпечення гідної праці держслужбовців, тобто взаємопов'язаної й у міру узгодженої системи нормативно-правових, інституційних та організаційних форм і засобів, які в сукупності впливають на сторони службово-трудових правовідносин і на інших суб'єктів права, забезпечуючи так упровадження в практичній дійсності належного рівня відповідності праці на державній службі критеріям (вимогам) концепції гідної праці.

Додатково актуалізує потребу в дослідженні вказаних категорій той факт, що мета й цілі функціонування відповідного правового механізму ще не досліджувалася в українській і зарубіжній науці трудового права (також і в межах науки адміністративного права, у сфері науки державного управління).

Хоча окреслене питання ще не було предметом комплексного дослідження у вітчизняній і зарубіжній юридичній науці, варто звернути увагу на те, що окремі аспекти цього питання тією чи іншою мірою вже досліджувалися українськими юристами-трудовиками. Зокрема, Н.I. Бернацькою, В.В. Волинцем, О.А. Губською, Л.Л. Денісовою, О.Ю. Дроздом, Т.А. Занфіровою, М.I. Зубрицьким, М.I. Іншином, О.В. Карпушовою, М.М. Клемпарським, П.С. Луцюком, В.Я. Мацюком, К.Б. Пусан, Д.П. Ушверідзе й іншими вченими з'ясовувалася трудоправова природа службово-трудових правовідносин i/або уточнювався трудоправовий статус державних службовців.

Постановка завдання. Отже, метою наукової розвідки є окреслення загальної мети й похідних від неї стратегічних цілей функціонування правового механізму забезпечення гідної праці державних службовців в Україні. Досягнення цієї мети виявляється можливим у разі вирішення таких завдань: (1) з'ясування сутнісного змісту загальнонаукового поняття «мета»; (2) грунтуючись на концептуальному змісті понять «мета» й «функціонування правового механізму забезпечення гідної праці державних службовців», сформулювати визначення мети функціонування відповідного правового механізму; (3) з'ясувати комплекс основних стратегічних цілей функціонування правового механізму забезпечення гідної праці держслужбовців; (4) окреслити стратегічні напрями функціонування правового механізму забезпечення гідної праці державних службовців.

Результати дослідження. Поняття «мета» в наукових дослідженнях і розвідках ученими 
переважною мірою розкривається однаково. Зокрема, українські науковці І.В. Шпекторенко та Є.I. Бородін уважають, що мета - це «усвідомлене уявлення, образ передбачуваного й очікуваного результату, на досягнення якого спрямована діяльність» [4, с. 47]. Вітчизняні науковці B.M. Тертишник та О.Г. Кошовий зазначають, що мета - це «уявна модель бажаного результату, яка міститься в «уяві» особи, не завжди викладається на папері чи в об'єктивному світі, а отже, не завжди доступна для сприйняття, аналізу» [4, с. 64]. У свою чергу, Д.В. Холодненко доходить висновку, що під поняттям «мета» варто розуміти «очікуваний, бажаний стан системи, що обов'язково передбачає досягнення заздалегідь визначеного результату і виступає в якості головного орієнтира контрольної діяльності». Крім того, вченим наголошується на тому, що мета має стратегічний характер, на відміну від завдань, що мають тактичний характер» $[5$, с. 105, 107].

Отже, беручи до уваги сутність поняття «мета» і сформульовану дефініцію «функціонування правового механізму забезпечення гідної праці держслужбовців», можемо дійти думки, що безпосередня (загальна) мета функиіонування правового механізму забезпечення гідної праці державних службовців виявляється в досягненні в практичній дійсності належного рівня впровадження критеріїв гідної праці у сфері державної служби за допомогою використання правових та інших інструментів, принципів, які сприяють розвитку концепції гідної праці й запобігають загрозам зниження рівня забезпечення гідної праці державних службовців.

Поряд із тим у практичній дійсності можуть також виникати випадки, коли запропоноване розуміння мети функціонування правового механізму забезпечення гідної праці держслужбовців на практиці буде невиправдано широко тлумачитися (як держслужбовцями, так і їхніми колегами, керівниками, суспільством та іншими), призводячи до викривлення концептуальної сутності відповідного механізму правового забезпечення. Задля уникнення формування практики широкого тлумачення означеної мети запропоновану дефініцію варто доповнити переліком стратегічно-функціонального вияву зазначеної мети, а саме такими цілями функціонування досліджуваного правового механізму:

1) забезпечення ідеї цінності людини та іï гідності в службово-трудових правовідносинах (безпосередньо стосовно державного службовця, що $є$ працівником, котрий володіє, окрім комплексу службово-трудових прав, також і правами людини) як цивілізаційної вимоги й одного 3 важливих орієнтирів побудови в Україні соціальної та правової держави;

2) зміцнення й розвиток трудових та інших прав і свобод державного службовця як людини, особистості. Правовий механізм забезпечення гідної праці держслужбовців у своєму функціональному прояві враховує те, що впровадження критеріїв гідної праці, з одного боку, вибудовується на основі зміцнення та розвитку комплексу наявних у держслужбовця прав і свобод (ефективне впровадження гідної праці можливе шляхом системних дій, спрямованих на забезпечення інших прав і свобод службовця, так чи інакше пов'язаних із його службово-трудовими правами), з іншого боку, є комплексною «формою» зміцнення відповідних прав і свобод службовця (забезпечення гідної праці сприяє зміцненню пов'язаних зі службово-трудовими правами службовця його особистими майновими та немайновими правами);

3) захист законних інтересів державного службовця в службово-трудових правовідносинах. У конкретному контексті мова йде не лише про суто трудові інтереси (праця в здорових і безпечних умовах, отримання гідної заробітної плати тощо), а й інші законні інтереси, що безпосередньо випливають із трудових, або ж ті, на які впливають умови трудової діяльності (особисте життя, непорушність приватності особистого життя тощо);

4) узгодження приватних і публічних інтересів у службово-трудових правовідносинах. Відповідний правовий механізм має основуватися на ідеї балансу в службово-трудових правовідносинах інтересів держави й інтересів держслужбовця як людини та працівника, а функціонування вказаного правового механізму - сприяти об'єктивації цьому балансу;

5) недопущення ігнорування критеріїв гідної праці на державній службі й усунення загроз, ризиків порушення цих критеріїв. Функціонування розглядуваного правового механізму охоплює не лише нормотворчу та виконавчу юридичну діяльність, а й саме правозастосовну діяльність державних органів, які мають сприяти високому рівню превенції від порушень права держслужбовця на гідну працю;

6) захист порушеного права держслужбовця на гідну працю та відновлення цього права. У практичній дійсності можуть мати місце випадки, коли інші стратегічні цілі функціонування правового механізму забезпечення гідної праці державних службовців не досягаються належною мірою (чи взагалі не досягаються). Утім указаним не вичерпується цільове функціонування зазначеного правового механізму. В інакшому випадку можна було б вести мову про те, що функці- 
онування досліджуваного правового механізму є неповним, недієвим. Саме тому функціонування цього правового механізму передбачає особливий вплив (через органи виконавчої чи судової влади, через недержавні органи) на сторін службово-трудових правовідносин у відповідних випадках, результатом чого має бути припинення порушення права держслужбовця на гідну працю та негайне відновлення цього права;

7) притягнення порушників права держслужбовців на гідну працю до юридичної відповідності. Упровадження концепції гідної праці загалом і на державній службі зокрема неможливе без того, щоб усі елементи, які протидіють відповідному процесу (діяльності), були ізольовані від цього процесу передбаченим законодавством чином. Безумовно, особливо важливим таким елементом $є$ компетентна особа, котра $є$ відповідальною за забезпечення права держслужбовця на гідну працю та порушує це право. Отже, у процесі свого функціонування правовий механізм забезпечення гідної праці вказаних суб'єктів трудового права передбачає притягнення винних у відповідних порушеннях до юридичної відповідності (а саме до дисциплінарної та/або матеріальної, адміністративної чи кримінальної відповідальності залежно від сутності порушення та його наслідків).

Зважаючи на викладене, можемо дійти думки, що у функціонально-стратегічному (цільовому) контексті сформульована нами основна мета функціонування правового механізму забезпечення гідної праці державних службовців (крізь призму з'ясованих стратегічних цілей функціонування цього правового механізму) може розумітися в межах таких стратегічних напрямів функціонування правового механізму забезпечення гідної праці зазначених суб'єктів трудового права:

1) у нормативному напрямі: створення недекларативних законодавчих і підзаконних актів нормативного характеру й актів програмно-стратегічного характеру, якими впроваджується юридично вивірена єдина державна політика стосовно втілення в практичну дійсність ідеї гідної праці як у приватному, так і в публічному секторі (тобто на державній службі);

2) у суто адміністративно-правовому напрямі: з огляду на те що гідна праця держслужбовців забезпечується також у межах дії адміністративного права, стратегічні цілі в цьому напрямі виявляються в такому:

а) здійсненні на належному рівні контрольно-наглядових функцій державних органів і їхніх структурних підрозділів (головним чином служби управління персоналом), посадових осіб (керівника державного органу та спеціаліста 3 питань персоналу), які відповідають за контроль і нагляд за дотриманням і впровадженням критеріїв гідної праці на робочому місці держслужбовця (як у загальному контексті, так і з приводу окремих категорій держслужбовців, зокрема осіб з інвалідністю, вагітних жінок-працівниць та інших). У цьому сенсі особливо очікуваними $є$ організація та здійснення моніторингу стану впровадження критеріїв гідної праці держслужбовців, а також контроль за реалізацією заходів забезпечення гідної праці держслужбовців (звісно, особливим чином указане стосується держслужбовців у сфері правоохорони, в якій забезпечення гідної праці пов'язано з найбільшими складнощами);

б) реалізації координаційної діяльності державних органів стосовно впровадження в практичній дійсності позитивної практики забезпечення гідної праці державних службовців;

в) здійсненні оперативних заходів стосовно впровадження нових стандартів гідної праці й запобігання і протидії виявленим порушенням (а також ризикам порушення) чинних стандартів гідної праці;

3) в інформаційно-заохочувальному напрямі: компетентні державні органи (іхні структурні підрозділи, посадові особи) оприлюднюють найкращу практику впровадження концепції гідної праці на робочому місці держслужбовця, складаючи й оголошуючи рейтинги державних органів, у яких найбільш повно забезпечується гідність держслужбовця в службово-трудових правовідносинах;

4) у концептуально-адаптивному напрямі: на державній службі впроваджується позитивний досвід зарубіжних держав стосовно реалізації концепції гідної праці на державній службі, враховуючи особливості публічної служби в Україні. Також проводиться комплексна практична методична робота щодо адаптації українських умов проходження служби в держорганах до відповідних умов, у яких ураховано ідеологію гідної праці держслужбовців;

5) у напрямі превентивної, правозахисної та правовідновлювальної діяльності: державні органи (та недержавні інститути в межах своїх можливостей) виявляють ризики порушення права держслужбовців на гідну працю, захищають порушене право держслужбовців на гідні умови праці та відновлюють це право.

Висновки. Правовий механізм забезпечення гідної праці державних службовців є юри- 
дичною конструкцією, у межах функціонування якої здійснюється діяльність, об'єктивуються процеси, які окремо чи сукупно підтримують рівень відповідності праці на державній службі критеріям гідної праці, сприяють подальшому впровадженню ідеї гідної праці, а також захисту права держслужбовця на гідну працю, усувають суб'єктів, що становлять загрозу для панування концепції гідної праці в державних органах. При цьому раціональне функціонування розглядуваного механізму є можливим тоді, коли його функціонування підпорядковано не лише завданням (цілям), a і їх систематичному досягненню головним чином у межах відповідних напрямів об'єктивації правового механізму, а саме в нормативному напрямі; суто адміністративно-правовому напрямі; інформаційно-заохочувальному напрямі; концептуально-адаптивному напрямі; напрямі превентивної, правозахисної та правовідновлювальної діяльності.

\section{Список використаних джерел:}

1. Зубрицький M.I. Теоретико-методологічні та прикладні засади правового регулювання відносин у сфері юридичної відповідальності державних службовців в Україні : дис. ... докт. юрид. наук : 12.00.05. Київ, 2019. 422 с.

2. Бернацька Н.І. Проблеми правового регулювання соціального забезпечення публічної служби в Україні : дис. ... докт. юрид. наук : 12.00.05. Київ, 2018. 407 с.

3. Шпекторенко I.В., Бородін Є.I. Структура та методологія управлінської діяльності. Державне управління та місиеве самоврядування. 2018. № 3. С. 46-52.

4. Тертишник В.М., Кошовий О.Г. Проблеми юридичної визначеності інститутів протидії зловживанням на фондовому ринку. Наше право. 2018. № 2. С. 62-69.

5. Холодненко Д.В. Контроль та контрольна функція органів публічної адміністрації: цілі, мета, завдання. Правовий часопис Донбасу. 2018. № 2. С. 104-109.

УДК 349.2

DOI https://doi.org/10.32844/2618-1258.2019.3-2.4

ТІСЕЦЬКА А.А.

\section{ПРАВОВІ ГАРАНТІЇ ДЛЯ ЖІНОК ПІД ЧАС УКЛАДЕННЯ ТРУДОВОГО ДОГОВОРУ}

У статті проаналізовано специфіку правових гарантій для жінок під час укладення трудового договору. Виведено види відповідних гарантій. Досліджено зміст і значення кожної гарантії. Наголошено, що потреби працівників із сімейними обов'язками слід особливо враховувати під час планування умов праці та соціального забезпечення та слід заохочувати за допомогою поступового скорочення тривалості робочого часу і обсягу потрібної понаднормової роботи, а також шляхом впровадження гнучких схем у графіках роботи, періодах відпочинку та відпусток і шляхом впровадження еквівалентних умов зайнятості працівників, які працюють неповний робочий час, працівників, які працюють за тимчасовими угодами, та надомних працівників з умовами зайнятості працівників, які працюють повний робочий час. 3'ясовано, що на прохання вагітної жінки, жінки, яка має дитину віком до чотирнадцяти років або дитину-інваліда, в тому числі таку, що перебуває під іiі опікою, або здійснює догляд за хворим членом сім'ї відповідно до медичного висновку, роботодавець зобов'язаний встановлювати їй неповний робочий день або неповний робочий тиждень. Визначено, що при прийнятті на роботу в деяких випадках порушуються трудові права жінок через те, що вони не мають інформації про те, наскільки шкідливі або важкі для їх організму умови конкретної роботи, про особливості технології виробництва і загальний стан виробничих приміщень,

(С ТІСЕЦЬКА А.А. - юрист (ТОВ «ТЕХАРТБУД») 